\title{
Stemming Dokumen Teks Bahasa Bali Dengan Metode Rule Base Approach
}

\author{
Putu Gede Surya Cipta Nugraha ${ }^{1}$, Ni Wayan Wardani ${ }^{2}$ \\ STMIK STIKOM Indonesia; Jl. Tukad Pakerisan No.97 Panjer, 0361-246875 \\ Prodi Teknik Informatika, STMIK STIKOM Indonesia, Denpasar \\ Email : ${ }^{1}$ surya.cipta@stiki-indonesia.ac.id, ${ }^{2}$ niwayan.wardani@stiki-indonesia.ac.id
}

\begin{abstract}
Abstrak
Suku Bali adalah salah satu suku Bangsa Indonesia yang mayoritasnya berada di Pulau Bali, bahasa yang digunakan adalah Bahasa Bali dengan pedoman tiga tingkatan sor-singgih (tigang soroh) yaitu Basa Kasar, Basa Madia dan Basa Alus. Bahasa Bali juga memiliki imbuhan pangater, seselan dan pangiring. Untuk memudahkan pencarian kata dasar dalam Bahasa Bali perlu dilakukan proses stemming. Stemming adalah proses pemetaan dan penguraian bentuk dari suatu kata menjadi bentuk dasarnya. Proses stemming sangat penting didalam proses information retrieval system. Pada penelitian ini, dalam melakukan proses stemming Bahasa Bali menggunakan metode Rule Base Approach. Data yang digunakan dalam penelitian ini adalah kata dasar dalam Bahasa Bali sebanyak 376 kata dasar. Penelitian ini bertujuan untuk merancang aplikasi stemming yang tepat untuk melakukan stemming Bahasa Bali. Tahap awal dalam proses stemming Bahasa Bali adalah melakukan proses input, preprocessing, filtering, case folding dan tokenisasi. Masing-masing kata dilakukan proses stemming untuk menghilangkan imbuhan pangater, seselan, dan pangiring. Hasil dari penelitian menyatakan bahwa metode Rule Base Approach dapat digunakan untuk melakukan stemming teks Bahasa Bali, hal ini dapat dilihat dari hasil akurasi mencapai angka 77.82\%. Tentunya dalam pengujian masih terdapat kegagalan yang disebabkan oleh kesalahan overstemming akibat dari proses stemming.
\end{abstract}

Kata kunci-Bahasa Bali, Rule Base Approach, Stemming, Overstemming

\section{Abstract}

The Balinese are one of the ethnic groups of Indonesia, the majority of which are on the island of Bali, the language used is Balinese with three levels of sor-singgih (tigang soroh) guidelines, namely Basa Kasar, Basa Madia and Basa Alus. Balinese language also has the additions of pangater, seselan and pangiring. To facilitate the search for basic words in Balinese, a stemming process is needed. Stemming is the process of mapping and decomposing the form of a word into its basic form. The stemming process is very important in the information retrieval system process. In this study, the Balinese stemming process used the Rule Base Approach method. The data used in this study are 376 basic words in Balinese. This study aims to design an appropriate stemming application for Balinese stemming. The initial stage in the Balinese stemming process is to carry out the input process, preprocessing, filtering, case folding and tokenization. Each word is subjected to a stemming process to remove the additions of pangater, seselan, and pangiring. The results of the study indicate that the Rule Base Approach method can be used to stem Balinese texts, this can be seen from the results of the accuracy reaching $77.82 \%$. Of course, in testing there are still failures caused by overstemming errors resulting from the stemming process.

Keywords - Balinese language, Rule Base Approach, Stemming, Overstemming 


\section{PENDAHULUAN}

uku Bali adalah salah satu suku Bangsa Indonesia yang mayoritasnya berada di Pulau $\mathrm{S}$ Bali, bahasa yang digunakan adalah Bahasa Bali dengan pedoman tiga tingkatan sorsinggih (tigang soroh) yaitu Basa Kasar, Basa Madia dan Basa Alus. Morfologi bahasa Bali memiliki keunikan tersendiri jika dibandingkan dengan Bahasa Indonesia atau Bahasa Negara lain dalam hal penyusunan pengucapan, struktur kalimat, dan tata bahasa. Tata bahasa itu sendiri meliputi kata dasar, pangater (awalan), seselan (sisipan) dan pangiring (akhiran) dalam sebuah kalimat. Jika sebuah kata dasar dalam bahasa Bali sudah mendapatkan awalan, sisipan, akhiran atau kombinasinya maka kata tersebut disebut kruna tiron (kata berimbuhan). Kruna tiron merupakan Bahasa Bali yang memiliki arti kata berimbuhan yang terbentuk dari kata dasar yang mendapatkan awalan, sisipan dan akhiran. Kata dasar dalam Bahasa Bali yang sudah ditambahkan pengater, sisipan dan pangiring pasti memiliki permasalahannya sendiri jika diterapkan pada information retrieval.

Information retrieval merupakan metode mencari material (dokumen), meliputi proses mencari dan mengambil informasi berbasis pengetahuan dari kompulan dokumen (Roshdi \& Roohparvar, 2015). Information retrieval digunakan untuk mencari dokumen teks yang dibutuhkan oleh pengguna, dokumen teks tersebut berupa dokumen yang berbentuk digital (Afuan, 2013). Dalam mesin pencari (search engine) atau Information retrieval pada umum akan menghasilkan informasi dokumen teks dalam jumlah yang besar, hal ini juga akan memberikan dampak pada boros waktu dalam melakukan pencarian dokumen teks. Hasil pencarian informasi menggunakan search engine akan menghasilkan dokumen teks pencarian yang efektif dan efisien jika didukung proses pembuatan akar kata atau kata dasar yang tepat.

Dari permasalahan tersebut maka diperlukan aplikasi yang dapat mencari kata dasar dalam Bahasa Bali dengan memetakan pengater (awalan), seselan (sisipan) dan pengiring (akhiran). Semakin berkembangnya teknologi dan ilmu pengetahuan, untuk menentukan kata dasar dalam Bahasa Bali dapat direkomendasikan menggunakan Text Minning dengan tahap Stemming. Menurut Feldman (2007) text mining adalah sebuah proses pengetahuan intensif dimana pengguna berinteraksi dan bekerja dengan sekumpulan dokumen dengan menggunakan beberapa alat analisis sedangkan stemming adalah proses pemetaan dan menghilangkan bentuk dari suatu kata, sehingga kata tersebut menjadi bentuk dasarnya. Salah satu metode dasar yang banyak digunakan adalah metoda Rule Base Approach. Metode Rule Base Approach adalah metode yang membentuk akar kata dengan proses pengambilan awalan, sisipan dan akhiran.

Beberapa peneliti telah melakukan penelitian menggunakan metode Rule Based Approach antara lain oleh Guterres, A., Gunawan, \& Santoso, J (2019) dengan judul "Stemming Bahasa Tetun Menggunakan Pendekatan Rule Based", dengan hasil proses stemming Bahasa Tetun dalam penelitian ini memiliki tahapan yaitu memeriksa konfiks, memeriksa gabungan awalan $\&$ akhiran yang dilarang, dan memeriksa sisipan secara urut. Hal utama yang menjadi penyebabab kegagalan algoritma stemming Bahasa Tetun dalam proses stemming disebabkan karena kesalahan overstemming. Dalam penelitian ini algoritma stemming Bahasa Tetun mendapatkan tingkat akurasi sebesar $90.52 \%$. Melihat hasil akurasi yang sangat baik dari metode Rule Base Approach, penulis kembali menggunakan metode tersebut untuk melakukan stemming pada Bahasa Bali. Peneliti lainnya dilakukan oleh Amin, F., \& Alfa Razaq, J (2018), dengan judul "Implementasi Stemmer Bahasa Jawa Dengan Metode Rule Base Approach Pada Sistem Temu Kembali Informasi Dokumen Teks Berbahasa Jawa". Pada penelitian ini proses stemming pada dokumen teks Bahasa Jawa menggunakan metode Rule Base Approach dilakukan pada semua dokumen teks Bahasa Jawa. Pada penelitian ini hasil proses stemming Bahasa Jawa menggunakan metode Rule Base Approach mendapatkan tingkat akurasi yaitu sebesar $77 \%$. Melihat hasil akurasi yang sangat baik dari metode Rule Base Approach, penulis kembali menggunakan metode tersebut untuk melakukan stemming pada Bahasa Bali. Dari paparan 
penelitian sebelumnya, kontribusi ilmiah yang diterapkan yaitu penerapan metode Rule Base Approach untuk melakukan stemming pada Bahasa Bali.

Berdasarkan uraian latar belakang penelitian yang sudah peneliti paparkan serta melihat penting peranan stemming pada information retrieval dan mengacu pada hasil penelitian sebelumnya, peneliti tertarik untuk melakukan penelitian terhadap stemming dokumen dengan objek teks Bahasa Bali menggunakan metode Rule Base Approach. Peneliti berharap, dengan penelitian yang dilakukan, terciptanya aplikasi yang mampu mendapatkan kata dasar dari sebuah masukan dokumen teks Bahasa Bali.

\section{METODE PENELITIAN}

\subsection{Text Mining}

Menurut Feldman (2007) text mining adalah sebuah proses pengetahuan intensif dimana pengguna berinteraksi dan bekerja dengan sekumpulan dokumen dengan menggunakan beberapa alat analisis. Tahapan proses text mining dibagi menjadi 4 tahap utama yaitu Tokenizing, Filtering, Stemming, Tagging dan Analyzing. Tahapan-tahapan dalam text mining bertujuan untuk menemukan kata-kata yang mewakili isi dokumen dan digambarkan pada gambar 1. 


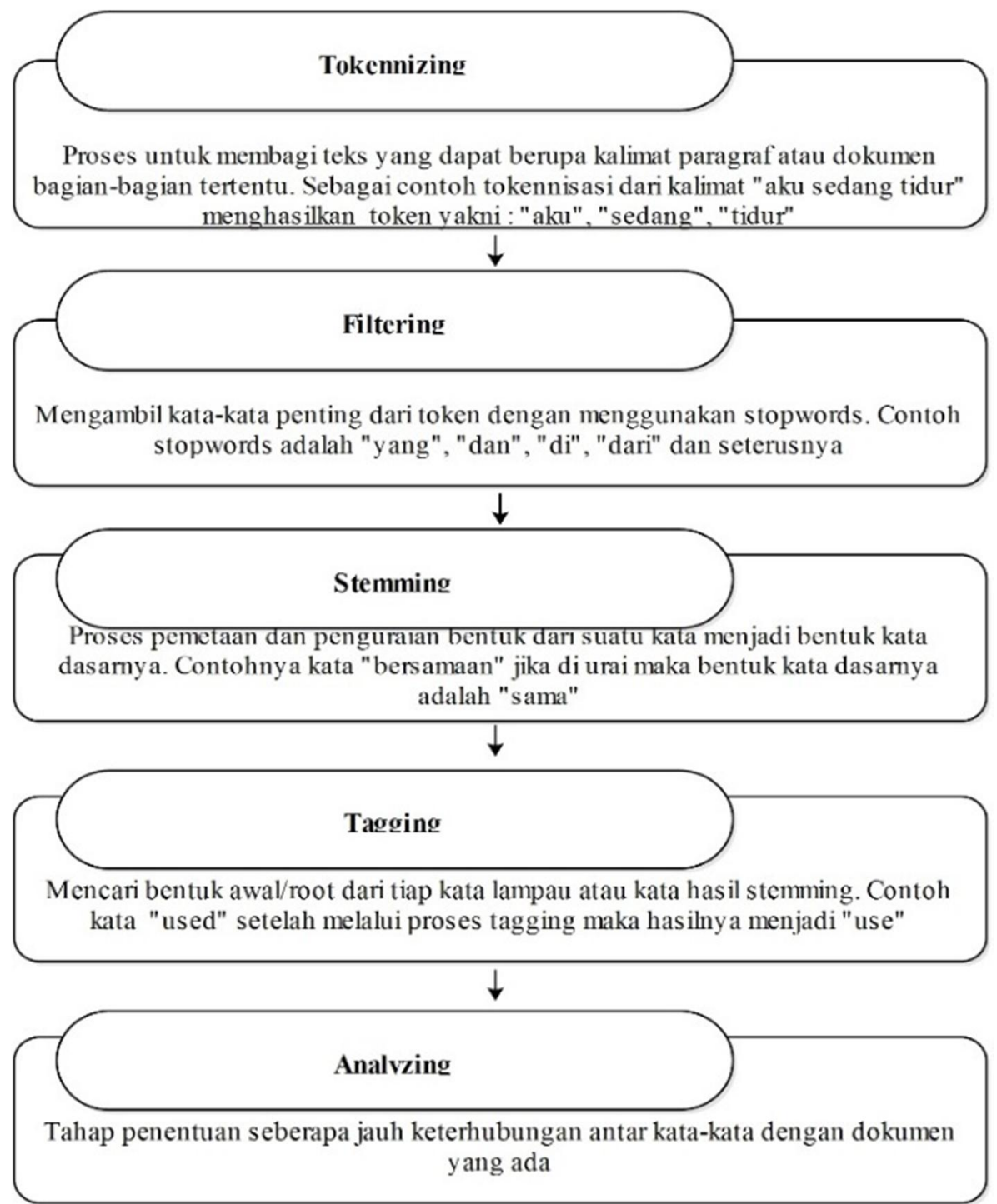

Gambar 1. Tahapan Dalam Text Mining

\subsection{Rule Base Stemmer}

Stemming adalah proses untuk menemukan akar kata (root) atau kata dasar dengan memisahkan semua affix atau imbuhan yang melekat pada kata tersebut. Affix (imbuhan) bisa terdiri dari awalan (prefix), akhiran (suffix), sisipan (infix), dan gabungan awalan-akhiran (confix). Pada banyak bahasa, kata-kata biasanya dihasilkan dengan menambahkan imbuhan pada kata dasarnya (root). Hasil dari stemming adalah stem (akar kata) yang merupakan bagian kata yang tersisa setelah dihilangkan imbuhannya (Amin, F., \& Alfa Razaq, J., 2018).

Metode Rule Base adalah metode yang membentuk akar kata dengan proses pengambilan awalan, sisipan dan akhiran. Metode Rule Base digunakan karena sifatnya yang fleksibel untuk digunakan sebagai stemmer berbagai macam bahasa dengan karakteristiknya yang lebih menekankan pada struktur morfologi suatu bahasa. Metode ini akan membuang (menghilangkan) prefix (awalan), suffix (akhiran) dan infix (sisipan) dari term bentukan menjadi suatu term kata dasar (Amin, F., \& Alfa Razaq, J., 2018). Algoritma Stemming bisa diklasifikasikan menjadi 2 (dua) yaitu Rule Based dan Statistical. Menurut Sharma (2012) Stemmer berbasis aturan mengkodekan aturan khusus bahasa dimana stemmer statistik 
menggunakan informasi statistik dari yang besar korpus bahasa tertentu untuk mempelajari morfologi. yang ditunjukan pada gambar 2 .

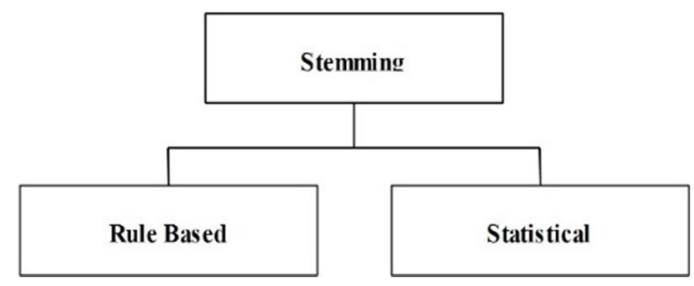

Gambar 2. Types of Stemming Approach (Sharma, 2012)

\subsection{Bahasa Bali}

Bahasa Bali adalah sebuah bahasa Austronesia dari cabang Sundik dan lebih spesifik dari anak cabang Bali-Sasak. Bahasa ini terutama dipertuturkan di pulau Bali, pulau Lombok bagian barat, dan sedikit di ujung timur pulau Jawa. Di Bali sendiri Bahasa Bali memiliki tingkatan penggunaannya, misalnya ada yang disebut Bali Alus, Bali Madya dan Bali Kasar.

Ada beberapa imbuhan dalam Bahasa Bali, yaitu:

a. Prefiks yaitu imbuhan yang diletakkan di awal kata dasar, dalam Bahasa Bali disebut dengan pangater terdiri dari: (a-, ma-, su-, ka-, pa-, pati-, pari-, maka-, saka-, kuma-, sa-, pa-, pi-, dur-, swa-). Adapun contoh katanya yaitu : aukud, majalan, sudharma, kaejuk, pajalan, patigrepe, makadadua, sakabesik, kumalipan.

b. Infiks yaitu penyisipan imbuhan di dalam kata dasar, dalam Basaha Bali disebut dengan Seselan terdiri dari: ( -in-, -um-, - el-, -er- ). Adapun contoh katanya : sinurat, sumaur, telapak, gerigi.

c. Sufiks yaitu imbuhan yang diletakkan di belakang kata dasar, dalam Bahasa Bali disebut dengan pangiring terdiri dari: ( - $a,-e$, -ne, -ang, -in, -an, - $n$, -wan, -nyane ). Adapun contoh katanya: alapa, bastise, memene, ngadepang, tulisin, menekan, bapan tiange, dharmawan

\subsection{Information retrieval}

Information retrieval merupakan metode mencari material (dokumen), meliputi proses mencari dan mengambil informasi berbasis pengetahuan dari kompulan dokumen (Roshdi \& Roohparvar, 2015). Information retrieval digunakan untuk menemukan kembali dokumen teks yang dibutuhkan oleh pengguna, dokumen teks tersebut berupa dokumen yang berbentuk digital (Afuan, 2013). Konsep pengambilan informasi (IR) telah dikembangkan dalam kaitannya dengan sistem database bagi banyak orang tahun. Pengambilan informasi adalah asosiasi dan pengambilan informasi dari sejumlah besar dokumen berbasis teks. Pengambilan informasi dan sistem database, masing-masing menangani berbagai jenis data; beberapa masalah sistem database biasanya tidak hadir dalam sistem pencarian informasi, seperti kontrol konkurensi, pemulihan, transaksi manajemen, dan pembaruan. Juga, beberapa yang umum masalah pencarian informasi biasanya tidak ditemui dalam sistem database konvensional, seperti sebagai dokumen tidak terstruktur, perkiraan pencarian berdasarkan kata kunci, dan konsep relevansi. Karena sejumlah besar informasi teks, informasi retrieval telah menemukan banyak aplikasi. Terdapat banyak sistem temu kembali informasi, seperti on-line sistem katalog perpustakaan, dokumen on-line sistem manajemen, dan baru-baru ini mengembangkan mesin pencari Web (Gupta, V., \& Lehal, G. S, 2009).

\subsection{Menghitung Akurasi Stemming}

Pada pengujian proses stemming menggunakan metode Rule Base Approach, dalam menghitung tingkat akurasi stemming dapat menggunakan persamaan (1). Pada persamaan (1), terdapat simbol x yang merupakan tingkat akurasi stemming. Simbol T merupakan jumlah kata 
yang di stemming dengan hasil benar. Simbol $\mathrm{N}$ merupakan jumlah kata yang di stemming (Husain, 2012).

$$
x=\frac{T}{\mathrm{~N}} \times 100 \%(1)
$$

\subsection{Rancangan Penelitian}

Secara umum, penelitian ini menghasilkan aplikasi yang dapat digunakan untuk pembentukan akar kata dalam dokumen teks Bahasa Bali. Analisa masalah penelitian ini dimulai dengan melakukan pengumpulan data dokumen teks Bahasa Bali serta bagaimana pengembangan atau memodifikasi tabel aturan pemenggalan dari algoritma Rule Base Approach.

Seperti terlihat pada gambar 3, pada proses studi literatur akan dilakukan pencarian referensi pendukung yang berupa teori maupun jurnal yang memuat penelitian terkait permasalahan yang telah didefinisikan sebelumnya. Pada proses analisa kebutuhan dilakukan pengumpulan kebutuhan yang diperlukan untuk memperkuat data penelitian yang selanjutnya dilakukan pemenuhan semua kebutuhan semua data tersebut pada proses pengumpulan data. Setelah semua data terpenuhi barulah dilakukan desain dan implementasi aplikasi tersebut. Untuk mengetahui kemampuan aplikasi dalam mengatasi permasalahan yang telah dikembangkan, maka dilakukanlah pengujian sistem. Proses paling akhir dari tahap penelitian ini adalah melakukan penarikan kesimpulan untuk penerapan solusi yang ditawarkan berdasarkan masalah yang telah didefinisikan sebelumnya.

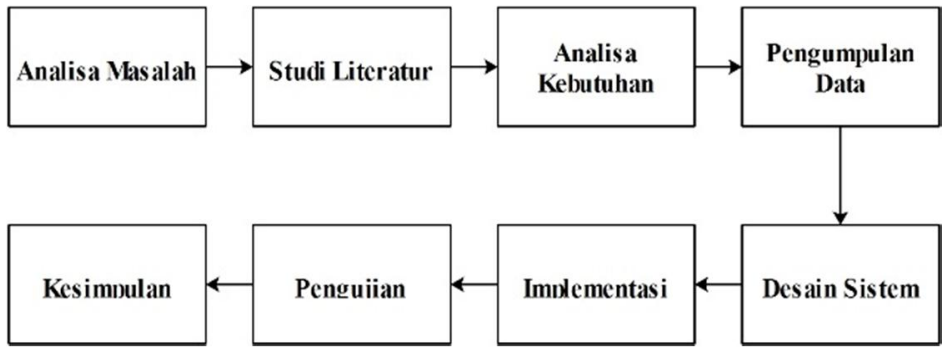

Gambar 3. Rancangan Penelitian Stemming Bahasa Bali

\subsection{Data yang Digunakan}

Data yang digunakan pada penelitian stemming Bahasa Bali, berupa kumpulan teks kata dasar yang menggunakan Bahasa Bali.

\subsection{Gambaran Umum Aplikasi}

Arsitektur umum pada sistem pembentukan akar kata dalam dokumen teks Bahasa Bali memiliki beberapa tahapan. Seperti terlihat pada gambar 4, adapun tahapan yang ada dalam sistem sebagai berikut:

1. Input

Pada tahap pertama sistem adalah input dokumen teks Bahasa Bali.

2. Preprocessing

Pada tahap preprocessing dilakukan proses perubahan bentuk teks yang belum terstruktur menjadi teks yang terstruktur, yang mana teks tersebut disesuaikan dengan kebutuhan aplikasi. Tahap yang dilakukan, yaitu:

a. Filtering

Pada proses filtering dilakukan pengambilan karakter alfabet dari dokumen teks Bahasa Bali. selanjutnya pada proses ini, dilakukan penghapusan karakter, tanda baca dan angka. 
b. Case Folding

Pada proses case folding dilakukan perubahan untuk semua huruf dalam dokumen teks Bahasa Bali menjadi huruf kecil. Huruf yang dapat diterima yaitu haruf 'a' sampai dengan huruf ' $\mathrm{z}$ '.

c. Tokenisasi

Proses ini bertujuan untuk memisahkan setiap kata yang menyusun dokumen menjadi kata per kata dengan menandai karakter spasi. Tiap kata hasil tokenisasi akan disimpan ke dalam katagori.

3. Proses

Pada tahap ini, dilakukan proses stemming dengan metoda Rule Base Approach. Satu per satu kata akan dicek, kata yang terdapat imbuhan akan dilakukan pengambilan imbuhan seperti awalan, sisipan atau akhiran sehingga terbentuk akar kata. Pembentukan kata dalam Bahasa Bali di paparkan pada struktur berikut:

\section{[awalan]+[sisipan] $+[$ dasar $]+[$ akhiran $]$}

Masing-masing imbuhan digabungkan dengan kata dasar sehingga membentuk kata berimbuhan baik yang berisi awalan, berisi sisipan, berisi akhiran maupun berisi semua model imbuhan. Pada stemming Bahasa Bali terdapat beberapa proses, proses tersebut adalah sebagai berikut:

a. Menghilangkan awalan (awalan-4, awalan-3, awalan-2 dan awalan-1)

b. Jika suatu aturan terpenuhi jalankan sbb :

- Hilangkan akhiran (akhiran-3, akhiran-2, akhiran-1)

- Jika suatu aturan terpenuhi, hilangkan awalan, jika tidak proses stemming selesai.

c. Jika tidak ada aturan yang terpenuhi jalankan sbb :

- Hilangkan awalan

- Hilangkan akhiran

- $\quad$ Proses stemming selesai.

4. Output

Setelah semua kata dalam dokumen selesai di proses, maka hasil dari proses stemming akan ditampilkan dalam bentuk teks. Kata yang di stemming awalan, sisipan dan akhiran akan diberikan tanda dengan warna biru dan warna merah. 


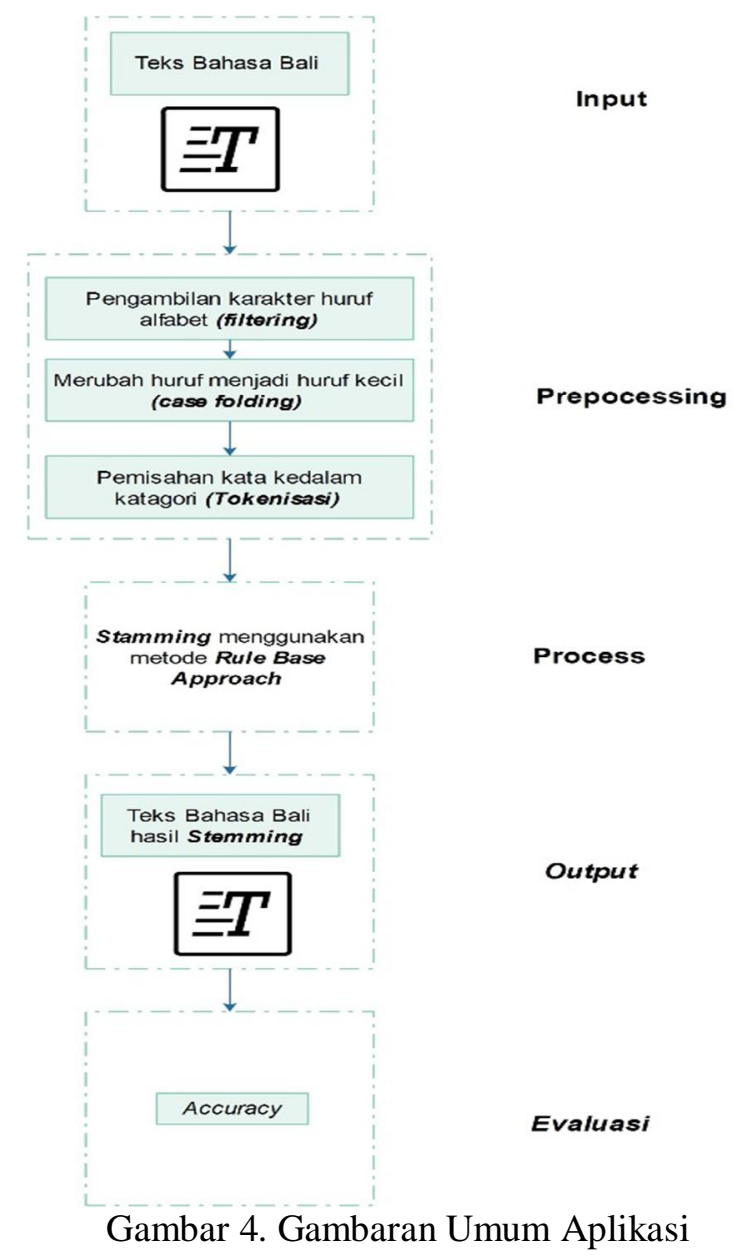

\section{HASIL DAN PEMBAHASAN}

\subsection{Sistem Pencaria Kata Dasar}

Data pada penelitian ini berupa kumpulan teks kata dasar yang menggunakan Bahasa Bali. Pada gambar 5 menampilkan tampilan aplikasi stemming, yang mana pada aplikasi ini terdapat 2 kolom. Masing-masing kolom memiliki fungsi yaitu untuk menampilkan teks awal dan menampilkan teks yang telah dilakukan proses stemming. Masukan dalam aplikasi ini yaitu load kamus, load leburan, load text dan load sisipan. Pada aplikasi stemming, untuk tahap awalan aplikasi memberikan tanda warna merah, pada tahap akhiran aplikasi memberikan tanda warna biru dan pada tahap sisipan aplikasi akan langsung memunculkan kata dasarnya. 


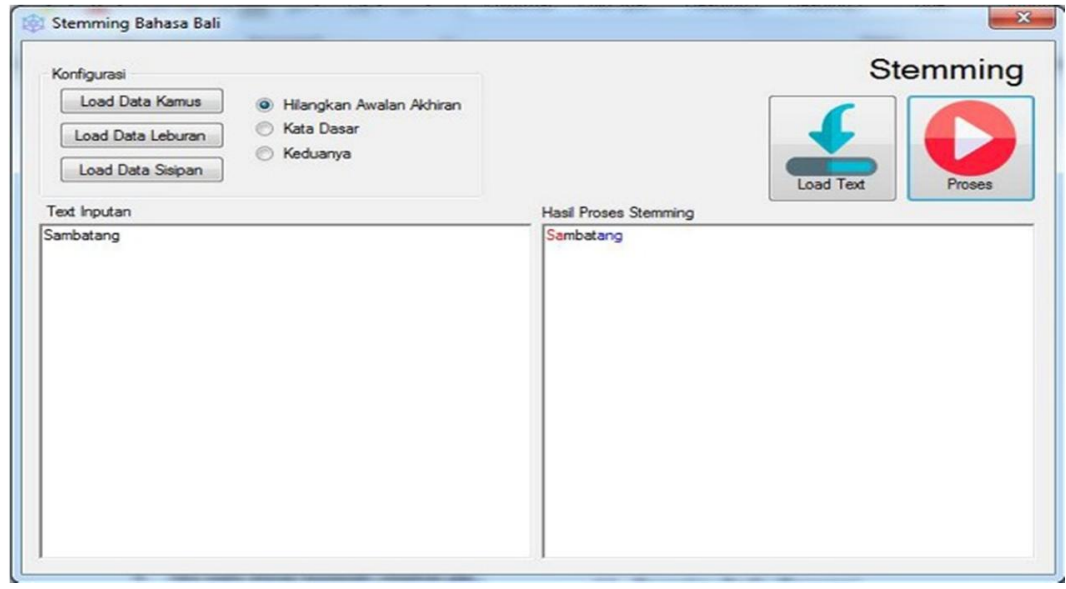

Gambar 5. Tampilan Sistem Pencarian Kata Dasar

\subsection{Pengujian Prefix (Pengater)}

Pada tahap ini dilakukan pengujian penghapusan pengater dari teks Bahasa Bali yang telah di masukan. Sebagai contoh "mabaju" bentuk dasarnya "baju". Pengujian dilakukan dengan menggunakan teks kata dasar pengater sebanyak 240 kata dasar.

Tabel 1. Pengujian Pengater

\begin{tabular}{|l|l|l|}
\hline Pengater & Teks & $\begin{array}{l}\text { Hasil } \\
\text { Stemming }\end{array}$ \\
\hline a & abungkul & bungkul \\
\hline ma & mabaju & baju \\
\hline ka & kajagur & jagur \\
\hline su & subhakti & bhakti \\
\hline pa & pangayah & ngayah \\
\hline pati & patikaplug & kaplug \\
\hline pari & parisolah & solah \\
\hline maka & makatelu & telu \\
\hline saka & sakabesik & besik \\
\hline kuma & kumajaum & jaum \\
\hline sa & sadurung & durung \\
\hline pi & pitutur & tutur \\
\hline dur & durlaba & laba \\
\hline swa & swabawa & bawa \\
\hline ng & ngalap & alap \\
\hline
\end{tabular}

\subsection{Pengujian Sufiks (Pangiring)}

Pada tahap ini dilakukan pengujian penghapusan pangiring dari teks Bahasa Bali yang telah di inputkan. Sebagai contoh "jemakin" bentuk dasarnya "jemak". Pengujian dilakukan dengan menggunakan teks kata dasar pangiring sebanyak 119 kata dasar.

Tabel 2. Pengujian Pangiring

\begin{tabular}{|l|l|l|}
\hline Pangiring & Teks & $\begin{array}{l}\text { Hasil } \\
\text { Stemming }\end{array}$ \\
\hline - a & jemaka & jemak \\
\hline$-\mathrm{e}$ & carike & carik \\
\hline
\end{tabular}




\begin{tabular}{|l|l|l|}
\hline - ne & bapanne & bapan \\
\hline - ang & dingehang & dingeh \\
\hline - in & negakin & negak \\
\hline - an & cenikan & cenik \\
\hline - n & mejan & meja \\
\hline
\end{tabular}

\subsection{Pengujian Infiks (Seselan)}

Pada tahap ini dilakukan pengujian penghapusan seselan dari teks Bahasa Bali yang telah di inputkan. Sebagai contoh "sinurat" bentuk dasarnya "surat". Pengujian dilakukan dengan menggunakan teks kata dasar seselan sebanyak 17 kata dasar.

Tabel 3. Pengujian Seselan

\begin{tabular}{|l|l|l|}
\hline Sisipan & Teks & $\begin{array}{l}\text { Hasil } \\
\text { Stemming }\end{array}$ \\
\hline -in- & sinurat & surat \\
\hline -um- & rumaksa & maksa \\
\hline -el- & telapak & tapak \\
\hline -er- & keresek & kesek \\
\hline
\end{tabular}

\subsection{Hasil Pengujian}

Setelah dilakukan pengujian stemming teks kata dasar pada pengater, seselan dan pangiring menggunakan aplikasi stemming kata dasar Bahasa Bali, dilihat hasil pengujian menghasilkan uji stemming benar pada pengater sebanyak 159 kata dan uji stemming salah pada pengater sebanyak 81 kata. Uji stemming benar pada seselan sebanyak 17 kata dan uji stemming salah pada seselan sebanyak 0 kata. Uji stemming benar pada pangiring sebanyak 80 kata dan uji stemming salah pada pangiring sebanyak 39 kata.

Tabel 4. Hasil Pengujian

\begin{tabular}{|l|c|c|c|}
\hline Imbuhan & $\begin{array}{c}\text { Jumlah } \\
\text { Kata } \\
\text { Dasar }\end{array}$ & $\begin{array}{c}\text { Uji } \\
\text { Stemming } \\
\text { (Benar) }\end{array}$ & $\begin{array}{c}\text { Uji } \\
\text { Stemming } \\
\text { (Salah) }\end{array}$ \\
\hline Pengater & 240 & 159 & 81 \\
\hline Seselan & 17 & 17 & 0 \\
\hline Pangiring & 119 & 80 & 39 \\
\hline
\end{tabular}

\subsection{Tingkat Akurasi}

Pada gambar 6 dapat dilihat tingkat akurasi aplikasi stemming kata dasar Bahasa Bali dengan metode Rule Base Approach, menghasilkan tingkat akurasi pengater 66,25\%, tingkat akurasi seselan $100 \%$ dan tingkat akurasi pangiring $67.22 \%$. Hasil rata-rata tingkat akurasi yang diperoleh aplikasi stemming Bahasa Bali sebesar 77.82\%. Dari hasil tingkat akurasi yang diperoleh dapat disampaikan bahwa aplikasi stemming kata dasar Bahasa Bali masih tergolong baik dalam melakukan proses stemming kata dasar Bahasa Bali. Jika mengacu pada hasil pengujian tepatnya dengan hasil uji stemming salah, masih terdapat banyak kesalahan pada proses stemming hal ini di karenakan Metode Rule Base Approach memiliki kelemahan yaitu jika diterapkan pada kata yang memiliki kompleksitas imbuhan yang tinggi dan aplikasi stemming tidak dapat mengenali rule maka akan terjadi kesalahan pada proses stemming. Selain itu penyebab kesalahan juga terjadi karena overstemming. Overstemming adalah sebuah permasalahan pada proses stemming dimana kata dasar dari hasil stemming mengalami kekurangan suku kata atau huruf yang dianggap sebagai imbuhan akibat dari proses stemming. 


\section{Tingkat Akurasi}

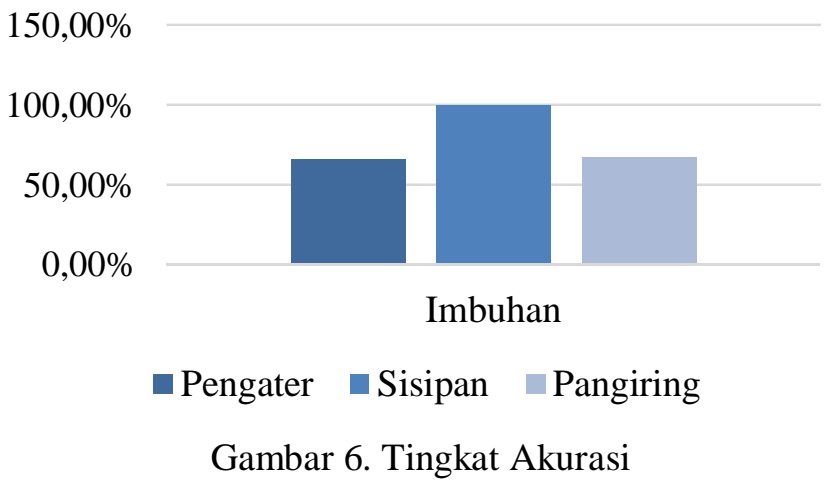

Dalam penelitian ini salah satu contoh permasalahan overstemming seperti proses pengiring "-ang" pada kata "sambatang" menjadi "mbat" padahal yang benar adalah "sambat". Dari hasil tersebut dapat kita lihat ada huruf atau suku kata yang menjadi bagian kata dasar yang terhapus atau hilang. Yang menjadi penyebab kegagalan pada proses stemming adalah karena ada bagian huruf yang dianggap sebagai pengater oleh aplikasi yaitu "sa", sehingga huruf atau suku kata tersebut dihapus.

Pada penelitian terdahulu metode Rule Base Approach sudah digunakan untuk melakukan proses stemming pada Bahasa Tetun yang mana penelitian dilakukan oleh Guterres, A., Gunawan, \& Santoso, J (2019). Jika dilakukan perbandingan hasil dari penelitian yang sudah dilakukan, dapat dilihat bahwa tingkat akurasi yang peneliti peroleh sebesar $77.82 \%$ lebih kecil jika dibandingkan dengan penelitian Guterres, A., Gunawan, \& Santoso, J sebesar 90.52\%, hal ini dikarenakan morfologi dari Bahasa Tetun sebagian besar masih menggunakan Bahasa Lain seperti Bahasa Indonesia dan Bahasa Portugis.

Pada penelitian terdahulu lainnya yaitu proses stemming pada Bahasa Jawa, yang mana penelitian dilakukan oleh Amin, F., \& Alfa Razaq (2018). Jika dilakukan perbandingan hasil penelitian yang sudah dilakukan, dapat dilihat bahwa tingkat akurasi yang peneliti peroleh sebesar 77.82\% sama jika dibandingkan dengan penelitan min, F., \& Alfa Razaq sebesar 77\%, hal ini dikarenakan morfologi Bahasa Jawa dan Bahasa Bali memiliki tingkat kesulitan yang hampir sama.

\section{KESIMPULAN}

Berdasarkan proses penelitian yang sudah dilakukan maka peneliti dapat mengambil kesimpulan bahwa metode Rule Base Approach dapat digunakan untuk melakukan stemming teks Bahasa Bali, hal ini dapat dilihat dari hasil tingkat akurasi mencapai angka $77.82 \%$. Tentunya dalam pengujian masih terdapat kegagalan yang disebabkan oleh kesalahan overstemming akibat dari proses stemming.

\section{SARAN}

Saran yang dapat penulis berikan untuk penelitian selanjutnya yaitu melakukan penelitian dengan menggunakan metode stemming lainnya atau melakukan kombinasi metode stemming lainnya dengan metode Rule Base Approach 


\section{UCAPAN TERIMA KASIH}

Penulis mengucapkan terima kasih kepada STMIK STIKOM Indonesia yang telah memberi dukungan financial terhadap penelitian ini.

\section{DAFTAR PUSTAKA}

[1] Afuan, L. 2013. Stemming Dokumen Teks Bahasa Indonesia Menggunakan Algoritma Porter, Jurnal Telematika Vol.6, 34-40, Jurnal Telematika

[2] Amin, F., \& Alfa Razaq, J. 2018, Implementasi Stemmer Bahasa Jawa dengan Metode Rule Base Approach pada Sistem Temu Kembali Informasi Dokumen Teks Berbahasa Jawa, Prosiding SENDI_U, 199-206, ISBN: 978-979-3649-99-3.

[3] Feldman, R., \& Sanger. J. 2007, Text Mining Handbook: Advanced Approaches in Analyzing Unstructured Data, Cambridge University Press, New York.

[4] Gupta, V., \& Lehal, G. S. 2009, A Survey of Text Mining Techniques and Applications, Journal of Emerging Technologies in Web Intelligence, 1 (1), 60-76. https://doi.org/10.4304/jetwi.1.1.60-76.

[5] Guterres, A., Gunawan, \& Santoso, J. 2019, Stemming Bahasa Tetun Menggunakan Pendekatan Rule Based, Teknika, 8(2), 142-147.

[6] Husain, M.S. 2012, An Unsupervised Approach to Develop Stemmer, Vol. 1(2), pp.15-23. International Journal on Natural Language Computing (IJNLC).

[7] Ramasubramanian, C., \& Ramya, R. 2013, Effective Pre-Processing Activities in Text Mining using Improved Porter's Stemming Algorithm, International Journal of Advanced Research in Computer and Communication Engineering, 2(12), 4536-4538. www.ijarcce.com

[8] Roshdi, A., \& Roohparvar, A. 2015, Review: Information Retrieval Techniques and Applications, International Journal of Computer Networks and Communications Security, 3(9), 373-377

[9] Sharma, D. 2012, Stemming Algorithms: A Comparative Study and their Analysis. Vol 4 (3), 2249-0868. International Journal of Applied Information Systems (IJAIS). www.ijais.org. 